\title{
Landscape Prediction and Mapping of Game Fish Biomass, an Ecosystem Service of Michigan Rivers
}

\author{
Peter C. Esselman*1 and R. Jan Stevenson \\ Department of Zoology, Michigan State University, 288 Farm Lane, Room 203, East Lansing, \\ Michigan 48824, USA
}

\section{Frank Lupi}

Department of Agricultural, Food, and Resource Economics, Michigan State University, 446 West Circle Drive, Room 202, East Lansing, Michigan 48824, USA; and Department of Fisheries and Wildlife, Michigan State University, 480 Wilson Road, Room 13, East Lansing, Michigan 48824, USA

\section{Catherine M. Riseng and Michael J. Wiley}

School of Natural Resources and Environment, University of Michigan, 440 Church Street, Ann Arbor, Michigan 48109, USA

\begin{abstract}
The increased integration of ecosystem service concepts into natural resource management places renewed emphasis on prediction and mapping of fish biomass as a major provisioning service of rivers. The goals of this study were to predict and map patterns of fish biomass as a proxy for the availability of catchable fish for anglers in rivers and to identify the strongest landscape constraints on fish productivity. We examined hypotheses about fish responses to total phosphorus (TP), as TP is a growth-limiting nutrient known to cause increases (subsidy response) and/or decreases (stress response) in fish biomass depending on its concentration and the species being considered. Boosted regression trees were used to define nonlinear functions that predicted the standing crops of Brook Trout Salvelinus fontinalis, Brown Trout Salmo trutta, Smallmouth Bass Micropterus dolomieu, panfishes (seven centrarchid species), and Walleye Sander vitreus by using landscape and modeled local-scale predictors. Fitted models were highly significant and explained $22-56 \%$ of the variation in validation data sets. Nonlinear and threshold responses were apparent for numerous predictors, including TP concentration, which had significant effects on all except the Walleye fishery. Brook Trout and Smallmouth Bass exhibited both subsidy and stress responses, panfish biomass exhibited a subsidy response only, and Brown Trout exhibited a stress response. Maps of reach-specific standing crop predictions showed patterns of predicted fish biomass that corresponded to spatial patterns in catchment area, water temperature, land cover, and nutrient availability. Maps illustrated predictions of higher trout biomass in coldwater streams draining glacial till in northern Michigan, higher Smallmouth Bass and panfish biomasses in warmwater systems of southern Michigan, and high Walleye biomass in large main-stem rivers throughout the state. Our results allow fisheries managers to examine the biomass potential of streams, describe geographic patterns of fisheries, explore possible nutrient management targets, and identify habitats that are candidates for species management.
\end{abstract}

The increasing integration of ecosystem service concepts into environmental management places a new emphasis on research addressing the ecological drivers of fish productivity. Ecosystem services are defined as components of nature that are directly enjoyed or consumed by humans or that are used to yield human well-being (Boyd and Banzhaf 2007). Biomass of target fish populations is a crucial "provisioning service" of ecosystems that has a high economic and cultural value to

*Corresponding author: pce@msu.edu

${ }^{1}$ Present address: U.S. Geological Survey, Great Lakes Science Center, 1451 Green Road, Ann Arbor, Michigan 48105, USA.

Received May 20, 2014; accepted November 6, 2014 
society (Millennium Ecosystem Assessment 2005). In Michigan alone, total expenditures by recreational anglers are estimated at more than $\$ 2.4$ billion annually (Southwick Associates 2007). Although the economic service values of Michigan's Great Lakes fisheries have been linked to fish catch rates (Melstrom and Lupi 2013) and fish productivity (Kotchen et al. 2006), the connection between ecosystem service values and fish productivity in rivers is poorly understood. An understanding of this connection is complicated because the species targeted by river and stream anglers are spread across heterogeneous landscapes with different capacities to provide fish to anglers and, by extension, differing capacities to accrue economic benefits to society. An understanding of which landscape conditions have the greatest potential to provide fish to anglers is a precursor to economic valuation and could facilitate strategies for maximizing this provisioning service of rivers. Maps of productive fish provisioning areas could be particularly useful to decision makers.

An important research question underlies the ability to map spatial variability in game fish availability to anglers: what factors constrain fish productivity at the landscape scale? If the constraints on measures of fish productivity (e.g., biomass) can be mapped continuously across the landscape, then it should also be feasible to model and continuously map the productivity of habitats. Previous work in rivers has identified a suite of local factors that are thought to constrain fish production. For instance, fishes in Michigan are strongly influenced by water temperature (Wiley et al. 1997; Wehrly et al. 2003; Zorn and Wiley 2006), which affects their metabolism and growth (Diana 2004) and has been correlated with fish presence and standing crops (Steen et al. 2008; Zorn et al. 2009). Other habitat characteristics that have been commonly associated with fish abundance or biomass are species dependent but include river depth, substrate, fish cover availability, and bank and riparian conditions (Jones et al. 1974; Hokanson 1977; Stuber et al. 1982a, 1982b; Johnson et al. 1988; Page and Burr 1991; Zorn and Wiley 2004).

Fish biomass has also been linked to concentrations of limiting nutrients, which are thought to act indirectly via a bottom-up trophic cascade to influence game fishes at higher trophic levels. For instance, Askey et al. (2007) found fivefold and 25-fold increases in biomass of Brown Trout Salmo trutta and Rainbow Trout Oncorhynchus mykiss, respectively, downstream from a municipal effluent source near Calgary, Alberta, and these increases were also accompanied by increases in invertebrate, macrophyte, and phytoplankton biomass. An 11fold to 73-fold increase in piscivore biomass was found below sewage effluents in a river near Montreal, Quebec, with Smallmouth Bass Micropterus dolomieu being among the greatest beneficiaries in terms of increased daily production (deBruyn et al. 2003). In experimental settings, bottom-up trophic cascades in response to phosphorus enrichment have been demonstrated to increase production at all trophic levels (Slavik et al. 2004), and salmonids have been shown to attain greater lengths and biomasses in response to nutrient additions (Johnston et al. 1990; Peterson et al. 1993; Slaney et al. 2003). Thus, in addition to temperature and other local habitat factors, nutrients are an important mediator of rivers' ability to provide fish to anglers.

The local habitat constraints on fishes are in turn constrained by landscape factors occurring at coarser spatial scales (Frissell et al. 1986). For instance, channel depth, velocity, substrate, and food availability are all strongly linked to upstream catchment area or longitudinal position within the river continuum (Vannote et al. 1980; Wiley et al. 1990; Rahel and Hubert 1991; Poff 1997; Slaney et al. 2003). Landscape factors have been used previously to predict the productivity of river fishes, thereby creating the potential to map fish biomass continually as an index of fish availability to anglers. Zorn et al. (2004) used multiple linear regression to model standing crops of 63 Michigan fish species, and their models generally explained between $10 \%$ and $50 \%$ of the variance for game species. Steen et al. (2008) used classification tree models to predict and map abundance categories (low, medium, and high) of 93 fish species in Michigan rivers and obtained good classification accuracy (average of $76 \%$ correct classification across species). Species-habitat models using as many as 25 habitat variables explained between $35 \%$ and $91 \%$ of the variation in abundances of 11 fish species in the Genesee River basin, New York (McKenna et al. 2006), and other workers have also successfully modeled fish abundances by using landscape and local factors (e.g., Gido et al. 2006; Stanfield et al. 2006). Synthesis of prior work suggests that nonparametric machine learning modeling approaches perform favorably in comparison with linear models (McKenna et al. 2006) and that the inclusion of modeled local conditions (e.g., hydrology, nutrients, and temperature) with landscape variables can lead to greater predictive power (Zorn et al. 2004).

The primary goals of the current study were to (1) use models to predict game fish standing crops continuously across the entire state of Michigan by using landscape and modeled local habitat variables and (2) identify the strongest landscape constraints on the standing crops of economically important game fishes. Standing crops were thus treated as an indicator of a river's capacity to produce fish for anglers as an important provisioning service of waterways that yields benefits in the form of recreational and subsistence harvest (Boyd and Banzhaf 2007). We modeled standing crop (i.e., biomass density) rather than numerical density because standing crop is less affected by interannual variation in year-class strength (Zorn et al. 2004) and is a recommended indicator for ecosystem services (e.g., how much of the service is present; de Groot et al. 2010). Although biomass may be an imperfect measure of the availability of catchable fish to anglers, measures of catchable fish were not available for modeling. Furthermore, high biomass values in the Michigan Rivers Inventory data set were generally driven by the presence of large fish in a given sample (T. Zorn, Michigan Department of Natural Resources, personal communication), and a companion 
paper (Melstrom et al. 2015) demonstrated that fish biomass predictions across the landscape as generated by the current study were significantly correlated with angler choices about where to fish.

We were secondarily interested in testing hypotheses about game fish responses to total phosphorus (TP) concentrations. We focused on TP because (1) streams in Michigan tend to be phosphorus limited (Hart and Robinson 1990); (2) TP concentrations in water are significantly correlated with total fish standing crop (Hoyer and Canfield 1991; Randall et al. 1995); and (3) TP has been shown to drive positive (subsidy) responses in trout and bass fisheries (reviewed above). Thus, TP has the potential to increase the provision of fish to anglers. However, phosphorus is also a pervasive pollutant that can act as a stressor on stream ecosystems at higher concentrations (Miltner and Rankin 1998). Phosphorus-enriched streams support greater biomasses of benthic algae, macrophytes, and phytoplankton, which can lead to alterations in near-substrate flow velocities, dissolved oxygen, and $\mathrm{pH}$ dynamics (Welch et al. 1992; Dodds and Biggs 2002). These changes can be detrimental to sensitive species (Miltner and Rankin 1998), such as Brook Trout and Smallmouth Bass, leading us to hypothesize that these two species would respond positively to TP at low concentrations (a subsidy response) and negatively at higher concentrations (a stress response). More tolerant species, such as many sunfishes and Brown Trout, were expected to show only a subsidy response. Because Walleyes Sander vitreus make long in-channel migrations for spawning and are often sampled during their migration, we hypothesized that Walleyes would exhibit no response to nutrient levels at their place of capture. Below, we describe our approach to modeling and testing our nutrient effect hypotheses, present our model results, and describe our predictions of fish biomass as an indicator of Michigan rivers' potential to provide fish to anglers.

\section{METHODS}

Study site.-Michigan is divided geographically into the Upper Peninsula (UP) and Lower Peninsula (LP) at the point where Lake Michigan meets Lake Huron (Figure 1). The state is drained by approximately $85,000 \mathrm{~km}$ of streams that discharge into Lakes Erie, Huron, Michigan, and Superior. There are few high-gradient streams in the state, which has a low elevational range (174-603 $\mathrm{m}$ above sea level) and many wetlands. The surficial geology in much of the LP is dominated by glacial till and outwash deposits, the presence of which lead to high infiltration rates, high groundwater discharge, stable hydrology, cold water temperatures, and generally low nutrient concentrations (Olcott 1992; Wiley et al. 1997; Zorn et al. 2009). Cold water temperatures in the UP also result from the colder air temperatures at these northern latitudes and from the higher amounts of forest cover. The southeastern portion of the LP (i.e., from Saginaw Bay to the southern border of the state) deviates from the general pattern of till and outwash geology and is characterized by fine-textured lake plain deposits or postglacial alluvium. Streams in this area have lower infiltration rates, cool and warm surface waters, more flashy flow regimes, and higher natural nutrient concentrations. Distinctive fish communities are associated with coldwater and warmwater streams (Wiley et al. 1997; Zorn et al. 2002; Wehrly et al. 2003). Streams in the southern LP and main-stem rivers of the UP have summer temperatures that exceed $19^{\circ} \mathrm{C}$, a threshold above which warmwater communities are found in Michigan (Wehrly et al. 2003).

Data sources.-The fish data used in this study came from the Michigan Rivers Inventory database (Seelbach and Wiley 1997). Between 1982 and 1995, fish populations were sampled at 675 sites in the LP by using rotenone, electrofishing depletion, or mark-recapture techniques (methods are described in more detail by Seelbach and Wiley 1997 and Zorn et al. 1998). Rotenone samples were collected mostly in third- to fifth-order warmwater streams, and the weights of species captured and area sampled were recorded. Multiple-pass depletion sampling with electrofishing was conducted mostly in small (first- or second-order) streams by using two to five passes with block nets set at the upper and lower extents of most reaches. The biomass of each sample was estimated by using the following equation: $N_{i}=\left(N_{t} / C_{t}\right) \times C$, where $N_{i}$ is the estimated weight of species $i ; N_{t}$ is the total weight captured of species $i$; $C$ is the estimated weight of all species combined (after Zippin 1958); and $C_{t}$ is the combined weight of all species captured. Mark-recapture population estimates were made primarily for salmonids by using the Bailey modification (Cooper and Ryckman 1981). Our response variable was the estimated total biomass density ( $\mathrm{kg} / \mathrm{ha}$; standing crop) of different target species at a sampling site. Because some targeted sampling occurred, the number of sites available for model training varied among species from 335 to 397 sites spread across the LP (Figure 1). Targeted collection samples were only used in models of the species targeted.

The following fisheries were modeled: Brook Trout Salvelinus fontinalis, Brown Trout, Smallmouth Bass, Walleye, and panfishes as a group (Bluegill Lepomis macrochirus, Green Sunfish L. cyanellus, Pumpkinseed L. gibbosus, Redear Sunfish L. microlophus, White Crappie Pomoxis annularis, Black Crappie Pomoxis nigromaculatus, and Rock Bass Ambloplites rupestris). Standing crop values were $\log _{e}(x+1)$ transformed to improve normality and reduce the leverage of high observations.

Landscape environmental predictor variables (Table 1) were obtained from the Great Lakes Aquatic Gap Analysis Program (GLSC 2006) and the Classification and Impairment Assessment of Upper Midwest Rivers (Brenden et al. 2006). These databases contain GIS-linked databases with catchment, riparian, and channel data attributed to interconfluence stream reaches. The river line geometry was taken from the 1:100,000-scale National Hydrography Dataset (USEPA and USGS 2005) with modifications to provide a more accurate 


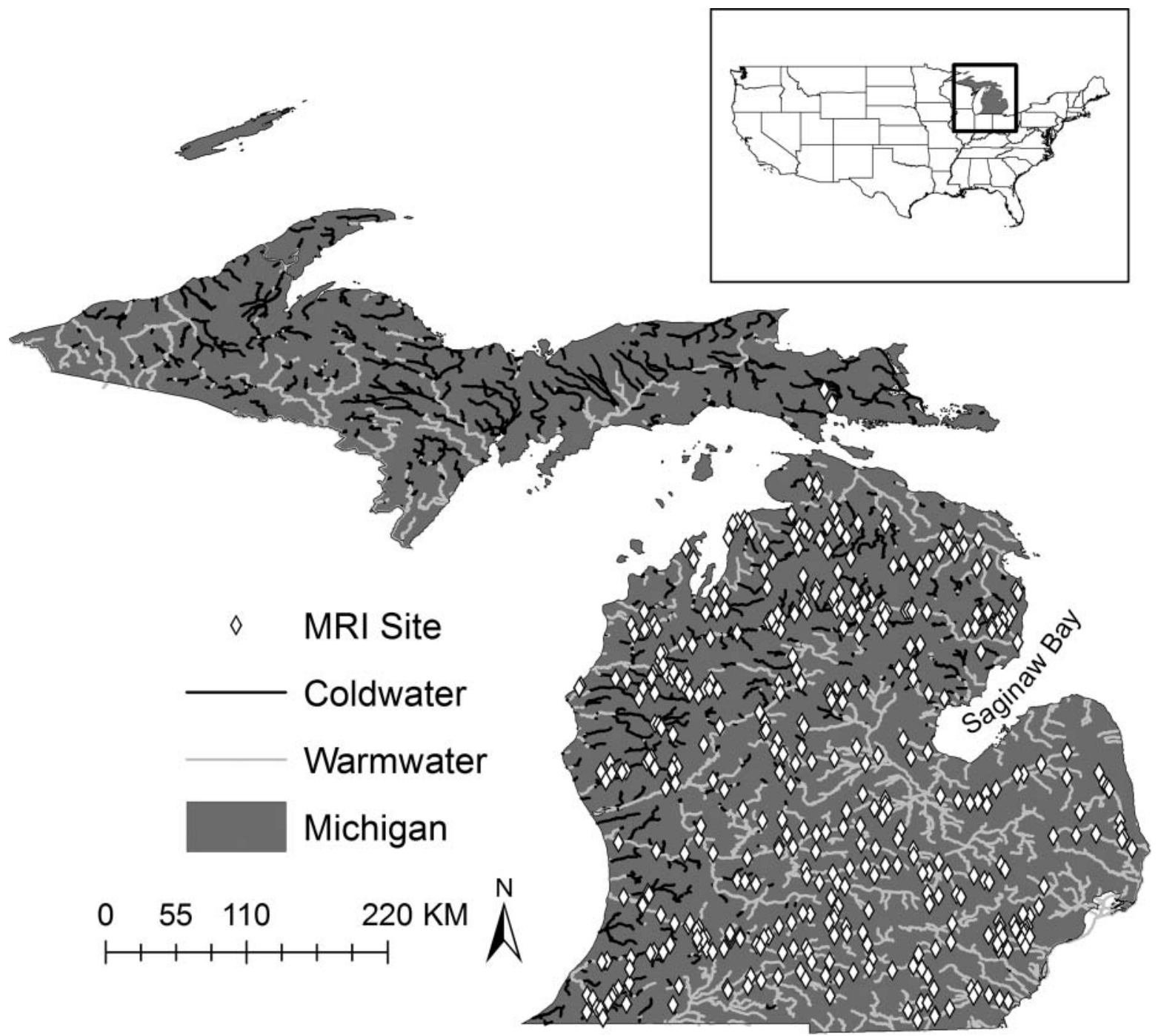

FIGURE 1. Locations of Michigan Rivers Inventory (MRI) sampling points for game fish standing crops. Not all points were sampled for all species. For the sake of clarity, only rivers with catchment areas greater than $50 \mathrm{~km}^{2}$ are shown.

representation of Michigan rivers (Brenden et al. 2006). The databases contain approximately 320 variables for 31,817 stream reaches, including information about soil permeability, 1998 land cover, stream position, bedrock and surficial geology, climate, modeled hydrology, and modeled July mean stream temperatures (Brenden et al. 2006). Modeled summer TP concentrations (P. Esselman and R. J. Stevenson, unpublished data) were used to represent local nutrient conditions. The TP model explained more than $50 \%$ of the variation in a test data set of base flow TP concentrations and was used because it is superior to other TP estimates available for Michigan (Kleiman 1995). Reaches that had no upstream dams were attributed with an arbitrarily high value of $100,000 \mathrm{~m}$ for the "distance to upstream dams" variable to avoid missing values.

Fish standing crop models.-A boosted regression tree (BRT) model (Friedman 2001; Elith et al. 2008) was trained for each fishery considered. Boosted regression trees are good for the modeling problem at hand because they have generally high predictive performance and offer a clear way to describe potentially nonlinear statistical relationships between independent variables and a response. The latter characteristic of these models was necessary to test our hypotheses about subsidy and stress responses to TP concentration. We trained a model for each of the fish species by using the gbm.step algorithm of Elith et al. (2008) for the gbm package in R (R Development Core Team 2013). The algorithm progressively reduces predictive deviance until a stopping point is reached; the stopping point used was the point at which the average cross-validation deviation ceased to improve. Cross validation was performed after the addition of each set of 50 trees by dividing the data into 10 equal-sized subsets ("folds"), iteratively training the model with nine folds combined, and then calculating the deviation of predictions versus the held-out "test set" until all 
TABLE 1. Predictors used to model game fish standing crops in Michigan, including summary statistics for measured values of predictors across all sampling sites $($ Min $=$ minimum; Q25 $=25$ th percentile; $Q 75=75$ th percentile; Max $=$ maximum).

\begin{tabular}{|c|c|c|c|c|c|c|}
\hline Predictor variable & Min & Q25 & Median & Mean & Q75 & Max \\
\hline Upstream catchment area $\left(\mathrm{km}^{2}\right)$ & 1.3 & 37.7 & 189.5 & 712.3 & 636.1 & $14,103.5$ \\
\hline Channel gradient $\left({ }^{\circ} \times 1,000\right)$ & 0.0 & 0.7 & 1.2 & 2.5 & 2.6 & 27.5 \\
\hline Water temperature $\left({ }^{\circ} \mathrm{C}\right)$, predicted July mean & 12.3 & 17.5 & 20.3 & 19.9 & 22.2 & 26.2 \\
\hline $90 \%$ exceedance flow yield $\left(\mathrm{m}^{3} \cdot \mathrm{s}^{-1} \cdot \mathrm{km}^{-2} \times 1,000\right)$ & 0.1 & 1.2 & 2.7 & 3.4 & 4.9 & 13.5 \\
\hline $50 \%$ annual exceedance flow $\left(\mathrm{m}^{3} / \mathrm{s}\right)$ & 0.0 & 0.2 & 1.0 & 5.5 & 4.6 & 110.8 \\
\hline $50 \%$ exceedance flow in April $\left(\mathrm{m}^{3} / \mathrm{s}\right)$ & 0.0 & 0.7 & 3.2 & 12.4 & 11.6 & 215.6 \\
\hline $10 \%$ annual exceedance flow $\left(\mathrm{m}^{3} / \mathrm{s}\right)$ & 0.0 & 0.9 & 5.4 & 18.7 & 15.8 & 290.3 \\
\hline Predicted base flow total phosphorus $(\mu \mathrm{g} / \mathrm{L})$ & 8.4 & 14.9 & 28.9 & 37.8 & 51.5 & 165.7 \\
\hline Medium-grain surficial geology in the upstream riparian buffer $(\%)$ & 0.0 & 0.0 & 0.0 & 15.0 & 25.6 & 100.0 \\
\hline Coarse and outwash geology in the upstream catchment $(\%)$ & 0.0 & 37.5 & 81.4 & 67.5 & 99.0 & 100.0 \\
\hline Forest land cover in the local riparian zone (\%) & 1.7 & 54.7 & 70.8 & 65.8 & 82.7 & 99.1 \\
\hline Nonforested wetlands in the local riparian zone (\%) & 0.0 & 3.2 & 6.7 & 8.8 & 12.1 & 46.7 \\
\hline Upland forest cover in the local riparian zone (\%) & 0.0 & 14.1 & 24.0 & 28.2 & 39.1 & 85.3 \\
\hline Presence or absence of a dam downstream ( 0 or 1$)$ & 0.0 & 1.0 & 1.0 & 0.8 & 1.0 & 1.0 \\
\hline Distance to the nearest upstream dam $(\mathrm{m} / 1,000)$ & 0.1 & 7.7 & 25.7 & 52.1 & 100.0 & 100.0 \\
\hline Presence or absence of a dam upstream ( 0 or 1$)$ & 0.0 & 0.0 & 1.0 & 0.7 & 1.0 & 1.0 \\
\hline
\end{tabular}

folds were used as test sets. The learning rate of each model was adjusted so that the cross-validation predictive deviance was minimized at between 1,500 and 3,500 trees.

A nonparametric permutation test was used to assess overall model significance. To implement this test, 1,000 data sets were created by randomizing the measured values of response variables. One-thousand models were run by using these data sets, and the cross-validation deviance of each model was recorded. The distribution of null deviance values was then compared to the model. The significance value $(P)$ was calculated as the probability that the nonrandomized cross-validation deviance measured in the actual fishery was less than or equal to the mean of deviance values of all permutations assuming a standard normal distribution. After significance testing, the cross-validation results were used to examine (1) the precision of each fishery model based on the coefficient of determination $\left(R^{2}\right)$; and (2) each model's accuracy based on the root mean square error (RMSE). The $R^{2}$ value was adjusted for the number of variables in each model relative to the number of observations (Theil 1961). The slope of the best-fit line between observed and predicted standing crop values was interpreted as a measure of model bias; residuals from the cross-validation calculations were plotted and examined for nonrandom structure and correlations with predictors to determine unmodeled input-output behavior.

A unique set of predictor variables was used to model each fishery based on a literature review of local habitat constraints on the species of interest (Supplementary Table S.1 available in the online version of this article). These constraining variables were then matched to our data set. In some cases, the habitat constraints could be represented directly from our data set by using modeled variables (e.g., temperature, phosphorus, and hydrology) or GIS-derived variables (e.g., sinuosity and channel gradient). In cases where local habitat constraints could not be represented directly, we attempted to identify suitable landscape proxies for the variable. Landscape proxies were established either as those with significant support from the analysis by Zorn and Wiley (2004) or as those with high correlation strengths to the corresponding local habitat variable in the Michigan Rivers Inventory (Table S.1).

Each predictor's relative importance for a model was expressed as the percentage of the total squared error improvement that could be attributed to that variable (Friedman 2001). We tested for the statistical significance of a TP effect by using a nonparametric permutation test in which 1,000 models were run with randomly reordered TP values while holding all other variables constant. Significance $(P)$ was calculated as the probability that the relative importance of TP was greater than or equal to the mean relative importance value of all permutations assuming a standard normal distribution.

We interpreted partial dependence plots for each model to assess our hypotheses about the influence of TP concentration and the general effects of other variables. Partial dependence plots show the mean response of fish standing crops to a predictor after accounting for the average effects of all other predictors in the model (see Friedman and Meulman 2003). The $y$-axis of a partial dependence plot retains the original units of the response variable; thus, we were able to obtain insight into the magnitude of response that could be attributed to TP after controlling for the mean effects of other variables in the model. We used a bootstrap procedure whereby 1,000 models were run with a random selection of $75 \%$ of the data points to 
establish the 95\% confidence interval (CI) around each mean predicted partial dependence curve.

Standing crops were predicted to stream reaches and were mapped on a continuous scale. Although we did not train our models with samples collected in the UP, our LP samples encompassed a range of habitats similar to those found in the UP, so we felt justified in predicting fishery responses to landscape conditions there. We examined the precision of our reach-specific standing crop predictions by mapping the SD around the mean prediction from the bootstrap procedure described above.

\section{RESULTS}

\section{Model Performance}

All models were highly significant $(P<0.0001)$ when compared with a null distribution of predictive deviance values from the permutation test on randomized response variables. The BRT models explained between $50 \%$ and $87 \%$ of the variation in training data and between $22 \%$ and $56 \%$ of the variation in cross-validation data for the fisheries considered; on average, the models had relatively low RMSE values (Table 2). The strongest model was for panfishes, followed by Brook Trout and Smallmouth Bass, Brown Trout, and Walleye. Scatter plots of observed versus predicted standing crops showed that the pattern of zero-value observations had a strong influence on the slope of the best-fit line (Figure 2), thus leading to slightly negative intercepts and to characteristic patterns of residual distributions (Figure 3). Brook Trout and panfish models tended to overpredict the zero and low values of standing crop while underpredicting the higher standing crop observations (Figure 2), although slopes were close to 1.0 (Table 2). For the Brown Trout and Walleye models, the zero values were overpredicted, whereas many of the positive standing crop observations were underestimated. The Smallmouth Bass model did a better job at predicting zero-value observations than the Brook Trout and panfish models, and the best-fit line was well centered through the cloud of positive standing crop observations. Significant correlations between residuals and model predictors were not observed (at the $P<$
0.05 level), suggesting that little to no additional variation in standing crop could be accounted for by our predictor set.

The overprediction of zero values resulted in residual plots with a characteristic pattern of negative residuals for zerovalue observations, leading to a decreasing linear pattern of negative residuals in the lower left quadrant of each plot (Figure 3). This pattern indicates that our models tended to overpredict standing crops at sites where game fishes were not detected during sampling. Such a pattern may have resulted from including sites outside of the occupied range of each species, which would lead to overprediction of biomass values in potentially productive habitats that were unoccupied. Overprediction of biomass at sites with observed zero values may have also resulted from prediction to habitat conditions that are degraded by unmeasured variables. In our study, the primary anthropogenically influenced variable considered was TP, but some factors that are known to degrade fisheries potential (e.g., substrate embeddedness from fine sediments) could not be modeled. Thus, it is possible that observed zero-biomass values resulted from prediction outside of range boundaries, unmeasured stressors, or inefficient sampling. We believe that inefficient sampling was least likely to have been a factor, as intense sampling methods were used. To ameliorate inaccuracies associated with prediction outside of range limits, prior to mapping we masked our model predictions to only those river habitats that were predicted to be within the occupied range of each fishery as reported by Steen et al. (2008).

\section{Relative Importance of Predictors}

The predicted relative importance of variables was consistent with our understanding of controls on fish productivity in rivers. For instance, water temperature was the strongest predictor for all but the Walleye model, accounting for between $26 \%$ and $59 \%$ of the mean square error reduction in models of Brook Trout, Brown Trout, panfishes, and Smallmouth Bass (Table 3). Other variables with relatively high effect sizes included upstream catchment area, river flow, and TP concentration (Table 3). Total phosphorus concentrations had statistically significant effects for all models except the Walleye model (Table 2). The modeled relative importance of TP

TABLE 2. Model performance and results of significance tests $(N=$ number of sampling sites used; $\%$ occupied $=$ percentage of sampled sites with positive abundance; RMSE = root mean square error; training $R^{2}=$ adjusted $R^{2}$ for observed versus predicted values for training data; cross-val. $R^{2}=$ adjusted cross-validation $R^{2} ; \%$ TP import = relative importance of total phosphorus [TP] in each model, expressed as a percentage; TP significance $=$ statistical significance $[P$-values $]$ of TP importance in the model as judged from a permutation test; $\mathrm{NS}=$ not significant).

\begin{tabular}{lccccccrc}
\hline Model & $N$ & \% occupied & RMSE & Training $R^{2}$ & Cross-val. $R^{2}$ & Slope & \% TP import & TP significance \\
\hline Brook Trout & 335 & 61 & 0.82 & 0.69 & 0.43 & 1.20 & 18.70 & $<0.0001$ \\
Brown Trout & 388 & 46 & 1.37 & 0.58 & 0.30 & 1.33 & 9.20 & $<0.05$ \\
Panfishes & 397 & 17 & 0.89 & 0.76 & 0.55 & 1.16 & 9.00 & $<0.05$ \\
Smallmouth Bass & 367 & 51 & 0.75 & 0.87 & 0.43 & 1.18 & 14.90 & $<0.001$ \\
Walleye & 392 & 54 & 0.43 & 0.49 & 0.20 & 1.66 & 3.80 & NS \\
\hline
\end{tabular}



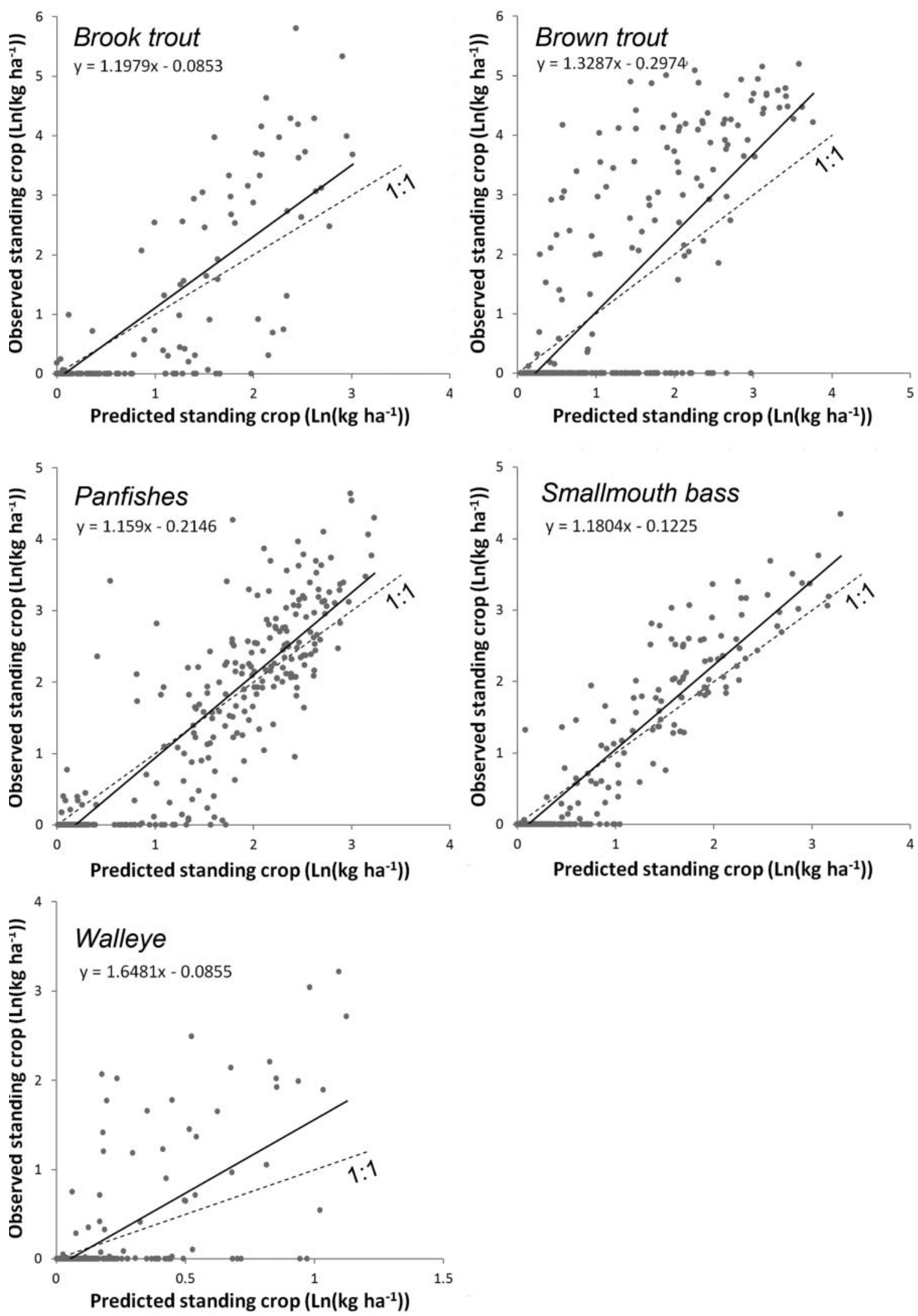

FIGURE 2. Observed versus predicted standing crops of Michigan game fishes for all sample data. 

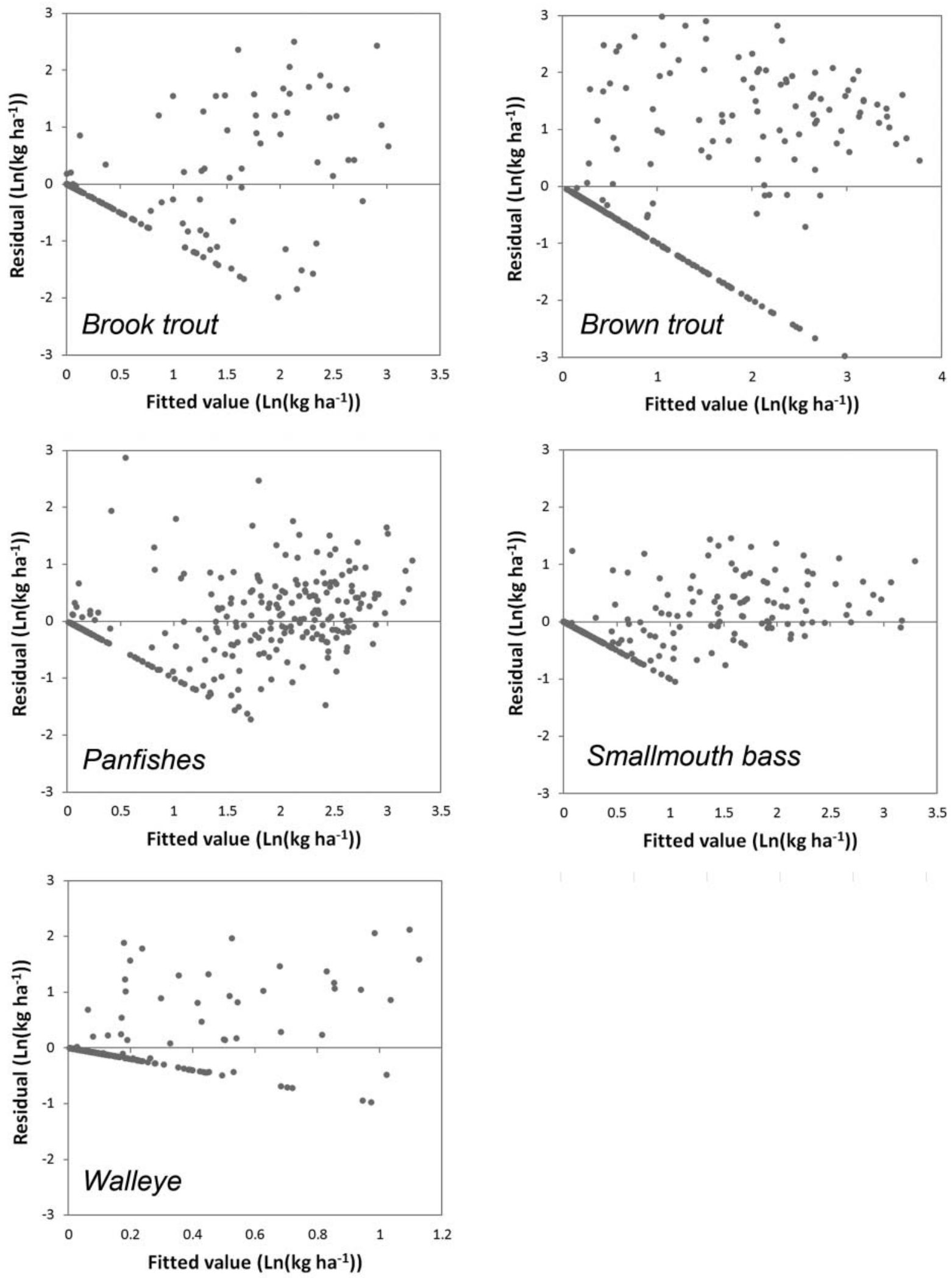

FIGURE 3. Residuals versus fitted values for predicted standing crops of game fishes in Michigan. 
TABLE 3. Relative importance values of each predictor included in each species model expressed as a percentage of the total squared error improvement over all models. See Table S.1 for details about predictor selection for each model. A dash indicates that the predictor was not utilized for the model.

\begin{tabular}{|c|c|c|c|c|c|}
\hline \multirow[b]{2}{*}{ Predictor variable } & \multicolumn{5}{|c|}{ Model } \\
\hline & Brook Trout & Brown Trout & Panfishes & Smallmouth Bass & Walleye \\
\hline Water temperature $\left({ }^{\circ} \mathrm{C}\right)$, predicted July mean & 58.7 & 29.6 & 55 & 26.1 & 10.4 \\
\hline Upstream catchment area $\left(\mathrm{km}^{2}\right)$ & 8.7 & 7.6 & 4.7 & 23.8 & 30.4 \\
\hline Predicted base flow total phosphorus $(\mu \mathrm{g} / \mathrm{L})$ & 18.7 & 9.2 & 9.0 & 14.9 & 3.8 \\
\hline $90 \%$ exceedance flow yield $\left(\mathrm{m}^{3} \cdot \mathrm{s}^{-1} \cdot \mathrm{km}^{-2}\right)$ & 6.4 & 21.4 & 3.8 & 10.9 & - \\
\hline Channel gradient $\left(^{\circ}\right)$ & - & 13.5 & 4.1 & - & 10.0 \\
\hline Forest land cover in the local riparian zone $(\%)$ & 7.5 & 8.7 & 5.4 & - & - \\
\hline $\begin{array}{l}\text { Medium-grain surficial geology in the upstream riparian } \\
\text { buffer }(\%)\end{array}$ & - & - & 3.6 & 13.2 & - \\
\hline Nonforested wetlands in the local riparian zone (\%) & - & - & 6.1 & - & 7.3 \\
\hline $50 \%$ exceedance flow in April $\left(\mathrm{m}^{3} / \mathrm{s}\right)$ & - & - & - & - & 29 \\
\hline Upland forest cover in the local riparian zone (\%) & - & - & - & 11.1 & - \\
\hline $10 \%$ annual exceedance flow $\left(\mathrm{m}^{3} / \mathrm{s}\right)$ & - & 10.0 & - & - & - \\
\hline $50 \%$ annual exceedance flow $\left(\mathrm{m}^{3} / \mathrm{s}\right)$ & - & - & 8.3 & - & - \\
\hline Distance to the nearest upstream dam (m) & - & - & - & - & 4.7 \\
\hline Coarse and outwash geology in the upstream catchment (\%) & - & - & - & - & 3.3 \\
\hline Presence or absence of a dam downstream ( 0 or 1$)$ & - & - & - & - & 1.0 \\
\hline Presence or absence of a dam upstream ( 0 or 1 ) & - & - & - & - & 1.0 \\
\hline
\end{tabular}

ranged from $9 \%$ to $19 \%$ for all fishes except Walleyes (relative importance of $\mathrm{TP}=3.8 \%$ ). Relative importance values of $\mathrm{TP}$ were significantly greater than the null distribution for Brook Trout $(P<0.0001)$, Smallmouth Bass $(P<0.001)$, panfishes $(P<0.05)$, and Brown Trout $(P<0.05)$ according to the results of the permutation test on TP only.

\section{Modeled Fish Responses to Predictors}

Partial dependence plots illustrated the modeled influence of TP concentration (Figure 4) and the other predictors (Figure S.1) on the mean responses of fish standing crops and allowed us to examine our subsidy and stress hypotheses. Fish responses to TP agreed with our hypotheses for Brook Trout and Smallmouth Bass (predicted subsidy and stress responses), panfishes (subsidy responses only), and Walleyes (no response). In addition, the TP concentrations at which subsidy and stress responses occurred varied depending on the fishery. As hypothesized, the mean response of Brook Trout and Smallmouth Bass biomass increased to a peak at low TP concentrations and then declined to relatively low levels as TP increased. However, the subsidy effect was not statistically significant for Brook Trout because mean biomass at a TP concentration of $13 \mu \mathrm{g} / \mathrm{L}$ did not exceed the $95 \%$ CI for mean biomass at $8 \mu \mathrm{g} \mathrm{TP} / \mathrm{L}$ (Figure 4). The decrease in Brook Trout biomass at TP values of 13 to $20 \mu \mathrm{g} / \mathrm{L}$ was statistically significant $(P<0.05)$. Smallmouth Bass biomass increased significantly between TP concentrations of 13 and $34 \mu \mathrm{g} / \mathrm{L}(P<$ 0.05 ) and decreased significantly at TP levels from 34 to
$50 \mu \mathrm{g} / \mathrm{L}(P<0.05)$, indicating that Smallmouth Bass are potentially less sensitive to the stressful effects of TP than are Brook Trout. The partial dependence plot for Smallmouth Bass (Figure 4) suggested that biomass increased at TP concentrations greater than $50 \mu \mathrm{g} / \mathrm{L}$, but due to the wide $95 \%$ $\mathrm{CI}$, the pattern was not significant relative to the minimum value.

Consistent with our hypothesis, panfish standing crops increased with increasing TP concentrations between 12 and $38 \mu \mathrm{g} / \mathrm{L}$ and thereafter remained at high levels (i.e., there was no obvious stress response across the range of TP concentrations studied). Contrary to expectations, Brown Trout exhibited a stress response to increased TP concentrations, as maximal biomass occurred at minimum TP concentrations and showed a declining trend as the TP level increased. Consistent with expectations, Walleye showed little response to TP, and 95\% CIs were wide.

Partial responses to other variables revealed sometimes strongly nonlinear patterns of fish standing crops in relation to landscape constraints. For instance, fishery responses to temperature were strongly nonlinear: the two trout species presented distinct associations with streams having colder July mean temperatures $\left(<18^{\circ} \mathrm{C}\right)$, while panfishes and Smallmouth Bass were associated with warmer waters $\left(>22^{\circ} \mathrm{C}\right.$; Figure S.1). Brook Trout tended to occur in streams with small upstream drainage areas and benefited from local riparian forest cover that was greater than $90 \%$. Brown Trout were predicted to benefit strongly from conditions with high discharge per unit area and higher channel gradients. Panfish biomass 

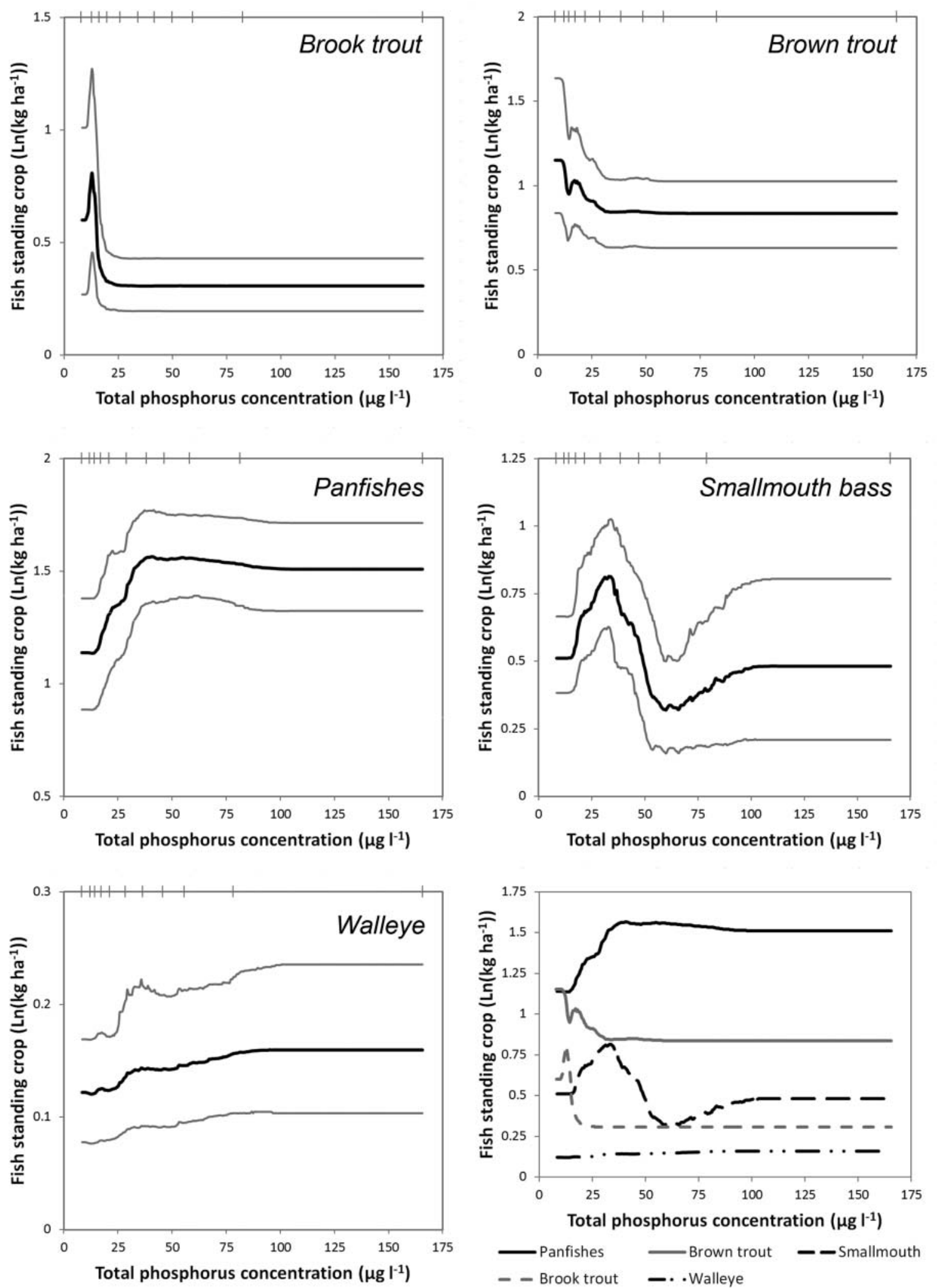

FIGURE 4. Partial dependence plots showing the predicted median response (black line) of target fisheries to predicted total phosphorus concentrations; the upper and lower boundaries of the 95\% confidence interval (gray lines) are also shown. Small vertical lines at the top of each plot show the frequency distribution of sites (in deciles). The bottom right plot depicts the median responses for all fisheries on the same response scale. 
was greatest in habitats with low median annual discharge magnitudes, higher proportions of nonforested wetland, and less forest cover within the local riparian buffer. Smallmouth Bass were constrained to warmwater streams with drainage areas greater than about $3,500 \mathrm{~km}^{2}$ and higher proportions of medium-textured surface geology in the upstream riparian corridor. Medium-textured geology in the upstream landscape may translate to greater availability of cobble substrates in local habitats, which has been positively associated with Smallmouth Bass biomass (Zorn et al. 2004). Walleye biomass was predicted to be greatest in streams with large upstream catchments $\left(>4,000 \mathrm{~km}^{2}\right)$ and high April flow volumes.

\section{Maps of Results}

Brown Trout were predicted to have the highest maximum biomass, followed by panfishes, Smallmouth Bass, Brook Trout, and Walleyes. However, predicted biomasses of panfishes and Brook Trout measured across their entire range in Michigan had higher means and medians than the biomasses of the other fisheries, including Brown Trout (Table 4). Brook Trout biomass was predicted to be greatest in the coldwater streams and rivers of the northern LP and streams draining north to Lake Superior in the UP (Figure 5). Streams with higher standing crop predictions corresponded well to those listed as "trout streams" and "Blue Ribbon trout streams" (www.trailstotrout.com/blueribbon.html) by the Michigan Department of Natural Resources (MDNR 2010). Brown Trout were predicted to occur at low relative biomass in streams throughout most of the LP, with patchy areas of higher biomass. Panfishes, a warmwater group, were predicted to be most abundant in small and large streams across the southern portion of LP, particularly in the southeast. Smallmouth Bass were predicted to be limited to main-stem habitats in larger rivers of the state, where warmer waters predominate. Walleye were predicted to occur at low biomass relative to the other species and to be limited primarily to main-stem rivers of the UP and western LP, but to inhabit smaller tributary systems bordering Saginaw Bay, Lake St. Clair, and Lake Erie.
Maps showing the uncertainty of our predictions enabled us to determine the streams and landscape contexts for which our predictions were least and most precise (Figure 6). The SDs of Brook Trout and Brown Trout biomass estimates were relatively low $(<0.5 \mathrm{~kg} / \mathrm{ha})$ for coldwater habitats of the northern LP and parts of the UP, whereas SDs were higher in the southern portion of the LP, where trout are generally known to be scarce. The majority of panfish standing crop estimates fell within $\pm 0.25 \mathrm{~kg} / \mathrm{ha}$ of the predicted value, particularly within main-stem rivers. Smallmouth Bass standing crop estimates tended to have SDs less than $0.5 \mathrm{~kg} / \mathrm{ha}$, except for small tributary streams at the margins of their occupied habitats. There was slightly greater variation around the mean predictions of Walleye standing crop, which was expected because the Walleye model was the least precise of the models we examined (Table 2). The low precision of the Walleye model may result from the fact that Walleyes are sampled when they migrate into river habitats to spawn, so their abundances in resident and migratory habitats have a high degree of spatiotemporal variability (Pritt et al. 2013).

\section{DISCUSSION}

We used statistical models to map the capacity of riverine habitats in Michigan to support fish biomass. Our models explained a relatively high proportion of variation in training (50-87\%) and test (22-56\%) data sets; despite their limitations (discussed below), the models may provide a useful tool for spatially extensive fisheries valuation, management planning, or other applications. Maps of reach-specific standing crop predictions for Michigan showed spatially structured patterns of predicted fish biomass that corresponded to spatial patterns in water temperature, land cover, and nutrient availability. Water temperatures are colder in the UP and northern LP, where trout were predicted to have higher standing crops, whereas temperatures are warmer in the southern LP, where Smallmouth Bass and panfishes occurred at high biomass densities.

Our results corroborate the findings of other studies that have examined ecological controls on fishes. Those studies established that stream temperature and hydrology (Fausch

TABLE 4. Summary statistics for the predicted standing crop of game fishes across all stream reaches in Michigan (Min = minimum; Q25 = 25th percentile; $\mathrm{Q} 75=75$ th percentile; Max = maximum). Percentage occupancy is given in parentheses.

\begin{tabular}{|c|c|c|c|c|c|c|c|}
\hline \multirow[b]{2}{*}{ Fishery } & \multirow[b]{2}{*}{ Occupancy $(\mathrm{km})$} & \multicolumn{6}{|c|}{ Predicted standing crop $(\mathrm{kg} / \mathrm{ha})$} \\
\hline & & Min & Q25 & Median & Mean & Q75 & Max \\
\hline Brook Trout & 30,321 (31) & 0.00 & 0.73 & 3.25 & 4.40 & 6.95 & 25.42 \\
\hline Brown Trout & $39,488(43)$ & 0.00 & 0.31 & 0.73 & 2.47 & 2.47 & 53.91 \\
\hline Panfishes & 39,943 (44) & 0.03 & 2.30 & 5.92 & 6.28 & 8.52 & 30.18 \\
\hline Smallmouth Bass & $6,022(7)$ & 0.00 & 1.06 & 2.41 & 3.34 & 4.77 & 25.87 \\
\hline Walleye & $10,694(12)$ & 0.01 & 0.16 & 0.22 & 0.34 & 0.283 & 2.22 \\
\hline
\end{tabular}



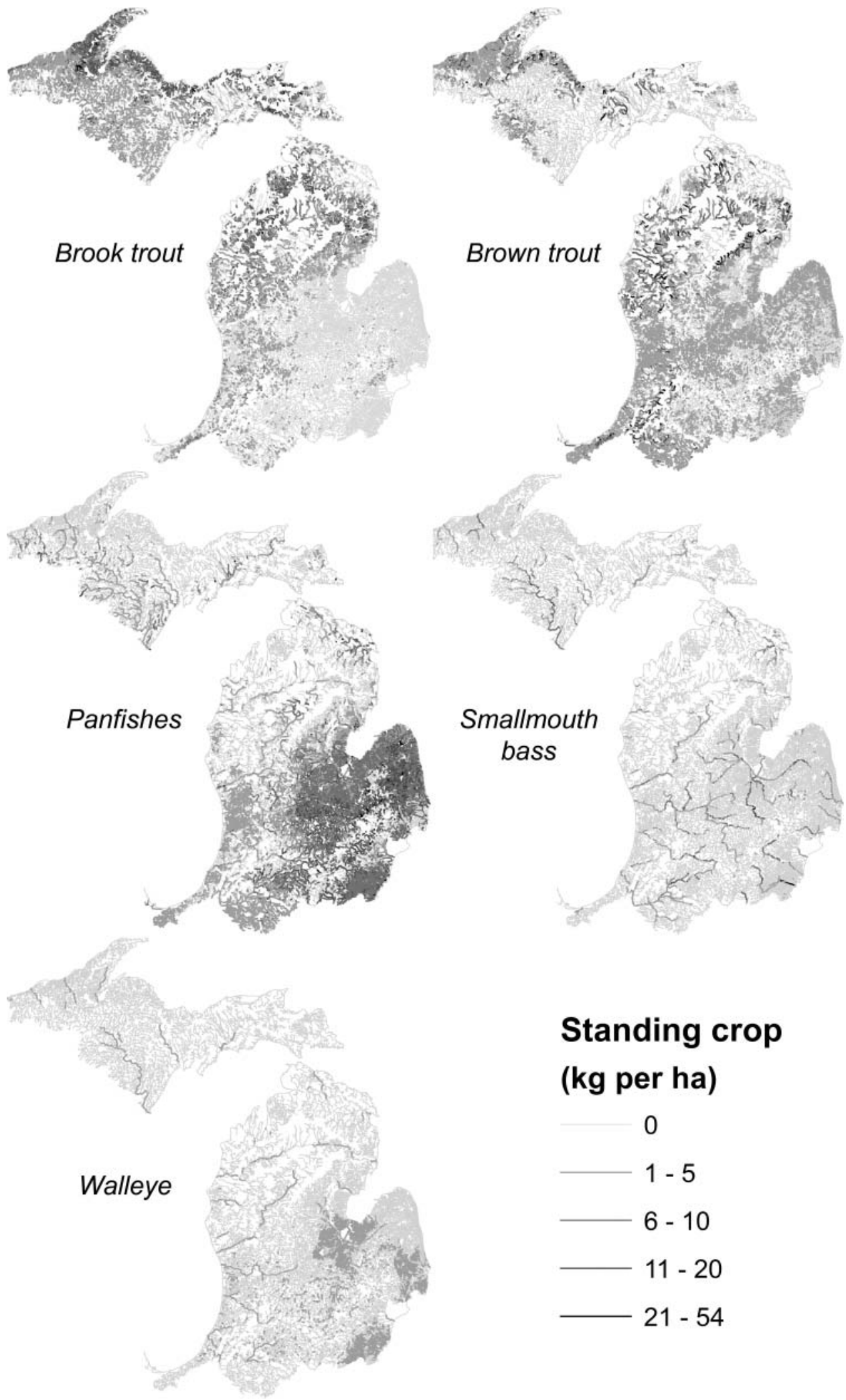

\section{Standing crop (kg per ha)}

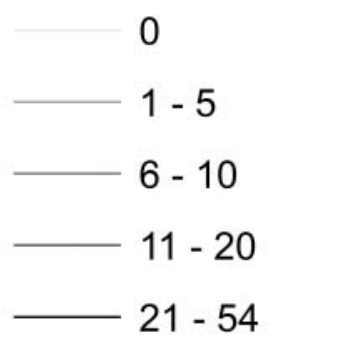

FIGURE 5. Spatial expression of model predictions mapped to individual stream segments in Michigan. Standing crops for each game fish are displayed on a common scale to allow direct comparison of biomass estimates. Reaches with zero predicted biomass and those predicted to be unoccupied by Steen et al. (2008) are not shown. 

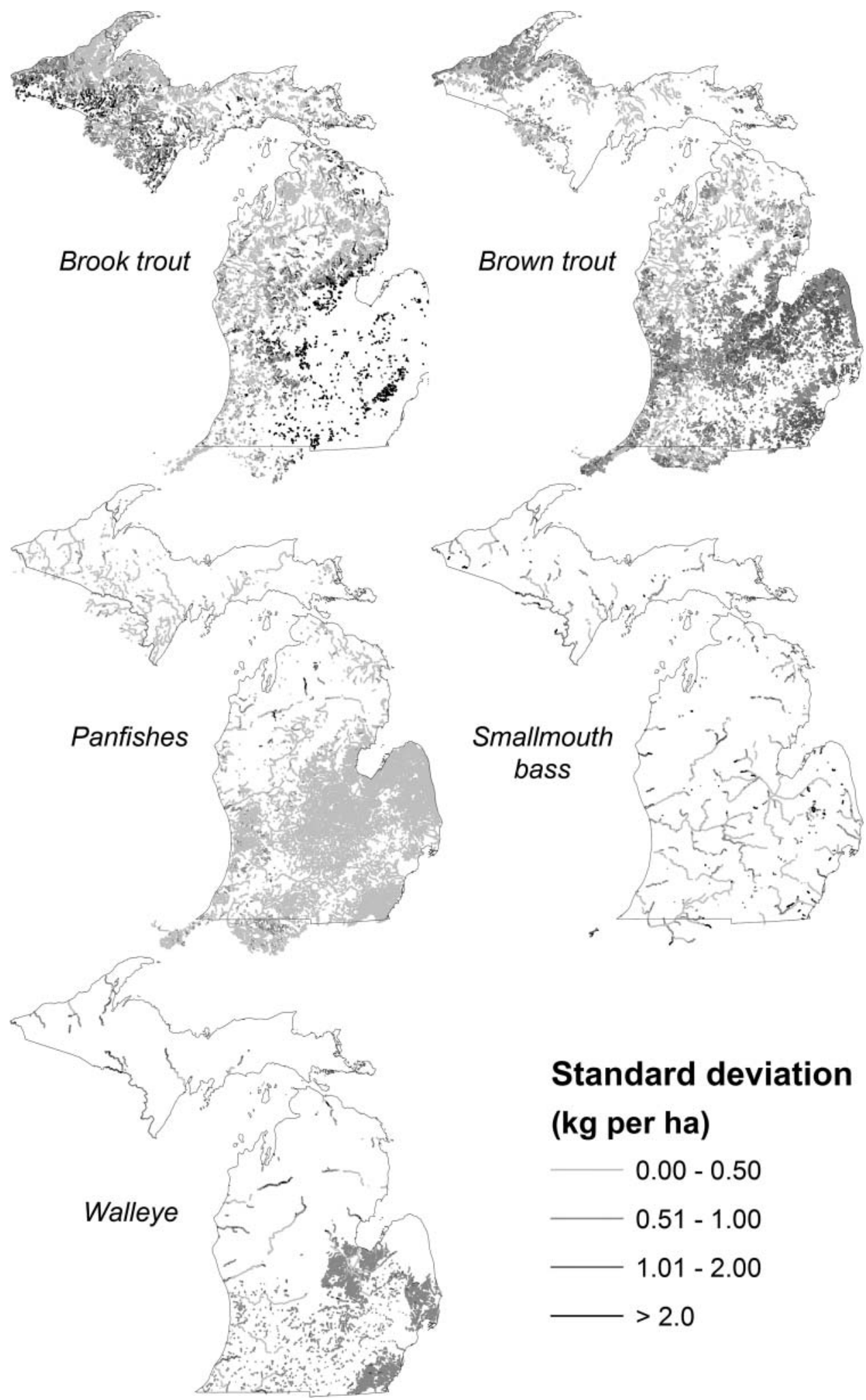

\section{Standard deviation}

(kg per ha)

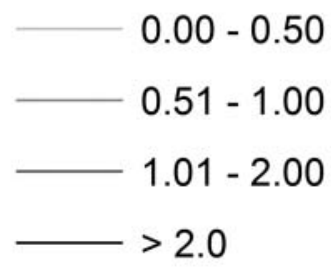

FIGURE 6. Estimated precision of game fish standing crop predictions for individual stream segments in Michigan, calculated as the SD around the mean predicted standing crop from 1,000 bootstrap samples of the training data. Reaches with zero predicted biomass and those predicted to be unoccupied by Steen et al. (2008) are not shown. 
et al. 1988; Lyons et al. 1996; Peterson and Kwak 1999; Stoneman and Jones 2000; Zorn et al. 2002; Creque et al. 2005; McRae and Diana 2005; Steen et al. 2008; Brewer and Rabeni 2011) as well as concentrations of limiting nutrients (Johnston et al. 1990; Hoyer and Canfield 1991; Waite and Carpenter 2000) are important influences on fish distributions and biomass across broad spatial extents. The fact that stream temperatures, hydrology, and nutrient concentrations were all modeled as local-scale variables emphasizes an important point made by de Groot et al. (2010): that the supply and management of ecosystem services must be approached as a problem that incorporates drivers across a range of scales. Our results suggest that incorporating reach-specific informationeven if the information is modeled — can be advantageous for the accuracy and ecological realism of predictive models.

Modeled fish responses to TP and other predictors (water temperature, hydrology, drainage area, and riparian land cover) were frequently nonlinear, exhibiting threshold, asymptotic, and hump-shaped responses (Figures 4, S.1). For instance, hump-shaped responses to TP concentration were evident for both Brook Trout and Smallmouth Bass, suggesting that TP subsidizes productivity to an optimum level after which stress effects become evident. A positive asymptotic relationship between panfishes and nutrient concentrations was apparent, suggesting subsidy effects only and a tolerance of high nutrient conditions (Figure 4). Previous studies have documented significant subsidy effects of growth-limiting nutrients on fishes, but few studies have documented stress effects. Strong experimental (Johnston et al. 1990; Peterson et al. 1993; Slaney et al. 2003), isotopic (deBruyn et al. 2003), and observational (Merron 1982; Askey et al. 2007) evidence supports bottom-up energetic subsidies as the likely mechanism by which nutrient enrichment benefits fish in rivers by increasing available food resources. In a study of Ohio streams, Miltner and Rankin (1998) observed the highest fish abundances at intermediate nutrient concentrations, whereas abundances of sensitive species were reduced at higher concentrations. Smallmouth Bass and Brook Trout have both been shown to be sensitive to habitat degradation (Sowa and Rabeni 1995; Argent and Flebbe 1999; Curry and MacNeill 2004; Stranko et al. 2008; Brewer and Rabeni 2011; Brewer 2013), pointing to one mechanism by which nutrient enrichment could be a stressor on fish. High concentrations of growth-limiting plant nutrients have been linked to an excessive growth of algae, macrophytes, and phytoplankton, which in turn can change habitat structure, flow velocities, dissolved oxygen concentration, and $\mathrm{pH}$ (Welch et al. 1992; Dodds and Biggs 2002). Other possible mechanisms for stress responses in Brook Trout and Smallmouth Bass include changes in insect prey availability (Miltner and Rankin 1998) and/or increased abundances of fish pathogens (e.g., Pseudomonas, Aeromonas, and myxobacteria) in eutrophic waters (Snieszko 1974). Although plausible mechanisms exist to support the subsidy stress responses observed, our findings were not derived from a controlled study but from an observational study, so they must be interpreted with caution due to our inability to account for potentially confounding stressors (e.g., fine sediment and habitat simplification) that co-occur with elevated nutrient concentrations (Carpenter et al. 1998; Smith et al. 2003).

Although not framed from an ecosystem services perspective per se, several other studies have modeled game fish abundances or biomass by using landscape-scale data (Sowa and Rabeni 1995; Zorn et al. 2004; Creque et al. 2005; McKenna et al. 2006; Stanfield et al. 2006; Steen et al. 2008; McKenna and Johnson 2011). Our study differed from these prior studies in terms of methods and response variables as well as the modeling approaches used. Choices of sampling methods and response variables are potentially important because not all methods for quantifying fishes are equally well suited to measure fish productivity as a provisioning service of ecosystems. For instance, Stanfield et al. (2006) used fish numeric densities (number per unit area) from single-pass electrofishing without any corrections for inefficient sampling. Numeric density is known to have higher interannual variation than biomass, and single-pass electrofishing provides a minimal estimate of the total abundance of each species at a site. Incomplete abundance estimates add an element of uncertainty to predictions of fish as a provisioning service and therefore would make maps less reliable. The depletion estimates, mark-recapture, and rotenone sampling used for this study and other studies (Sowa and Rabeni 1995; Zorn et al. 2004; Creque et al. 2005; Steen et al. 2008) provide estimates of total numeric abundance or biomass of the sampled population and thus offer a more objective basis for drawing conclusions about fish availability to anglers. Several authors (Steen et al. 2008; McKenna and Johnson 2011) chose to discretize continuous fish densities into $\log$-scale abundance categories $(0,1-10,10-100$, and $>100 \mathrm{fish} / \mathrm{unit}$ area). Although this approach may lead to improved goodness of fit by reducing variation in the response variable, modeling of continuous responses provides the potential for a better contrast in biomass between segments (Stanfield et al. 2006).

Our models performed favorably in comparison with other landscape models of abundances for the same game fish species (Sowa and Rabeni 1995; Zorn et al. 2004; Creque et al. 2005; Stanfield et al. 2006). Our Brook Trout model (training $R^{2}=0.68$; cross-validation $R^{2}=0.43$ ) explained more variation than the models of Creque et al. (2005; adjusted $R^{2}=$ 0.23 ) and Stanfield et al. (2006; adjusted $R^{2}=0.30$ ) and was comparable to the model of Zorn et al. (2004; $\left.R^{2}=0.47\right)$. Like other investigators, we found that Brown Trout were more difficult to model using landscape data than were Brook Trout. The performance of our Brown Trout model (training $R^{2}=0.58$; cross-validation $R^{2}=0.30$ ) and those of Stanfield et al. (2006; adjusted $\left.R^{2}=0.12\right)$ and Zorn et al. (2004; $R^{2}=$ $0.36)$ was low relative to the performance of the other models tested in each of the studies. Brown Trout may be challenging to model because they are nonindigenous fish that are actively 
stocked in some, but not all, places. Stocking of Brown Trout could lead to inflated standing crop estimates in some locations and therefore could increase the error variance for landscape models of trout productivity. Without spatially explicit information about where and how many Brown Trout were stocked, it was not possible for us to accommodate this aspect of their distribution and biomass. In contrast to our Brown Trout model, relatively strong Smallmouth Bass models were specified in our study (training $R^{2}=0.87$; cross-validation $\left.R^{2}=0.43\right)$ and in the studies by Zorn et al. $\left(2004 ; R^{2}=0.51\right)$ and Sowa and Rabeni (1995; adjusted $R^{2}=0.49$ ). Neither our study nor the Zorn et al. (2004) study was able to specify a strong model for Walleye distributions.

Although our models compared favorably with other published models, they have several notable biases and weaknesses. For instance, our models tended to overpredict standing crops at sites where sampling yielded zero biomass of game fishes (Figures 2, 3). This problem was also experienced by Zorn et al. (2004), who used a similar response data set. To avoid mapping biomass to unoccupied areas, we masked our predictions to only those reaches predicted to be occupied based on the work of Steen et al. (2008). It is possible that the inclusion of additional fish population stressors in future models could account for some of the observed zero values in the data set. Other models specifically formulated for such zero-inflated data (e.g., zero-inflated Poisson models; Lambert 1992; Wenger and Freeman 2008) may also be useful. However, zero-inflated Poisson models were not appropriate for the current study because of our interest in exploring possible nonlinear subsidy and stress responses to which BRTs are very well suited. For interpretation of our maps, the implication of overpredicting zero values is that low biomass values may in reality represent zero-biomass values and thus should be interpreted conservatively. In contrast, intermediate and high biomass values were relatively accurate for panfishes and Smallmouth Bass and were generally conservative for Brook Trout and Brown Trout. Therefore, intermediate and high values on our maps can be interpreted more reliably as average or conservative estimates of biomass density.

Two issues associated with our predictor and response data sets have implications for model accuracy. First, our response data were collected over a 13-year time span and thus give only a general picture of the capacity of habitats to support fish biomass that is not referenced to a specific time or population year-class. In reality, cohort density of some species (e.g., Smallmouth Bass) can fluctuate as much as $500 \%$ between years in relation to environmental conditions during the first year of life (Coble 1975). The fish biomass density in a specific river reach on a specific day may not correspond to our prediction because we could not account for year-class variation or other temporal effects. Second, our use of modeled predictor variables (water temperature, hydrology, and TP) introduces an additional source of error and unexplained variance. For instance, temperature model predictions were generally within $1^{\circ} \mathrm{C}$ or $2^{\circ} \mathrm{C}$ of actual weekly mean temperatures (Wehrly et al. 2003), but given the strong nonlinearities observed in response to temperature and several other variables, this amount of error could affect the accuracy of our mapped model predictions.

In addition to issues associated with model specification and data sets, fish life histories and interspecific interactions can create challenges for modeling fish biomass with high precision and accuracy. For example, Brook Trout and Brown Trout are known to make long-distance movements from the Great Lakes to river habitats to spawn in the fall (Horrall 1981). Migratory Brook Trout were likely absent from our samples because their remnant populations are primarily found in Lake Superior, where no samples were gathered. Migratory behavior by Brown Trout would tend to decrease the accuracy of our models, which assume that the fish reside (and are thus available to anglers) at the location where they were sampled. Interspecific competition is potentially important for models of Brook Trout and Brown Trout because competition for space and food between these species has been documented (Fausch and White 1981; McKenna et al. 2013). We did not model this potential biotic interaction for three reasons. First, in order to generalize from a model with biotic interactions included, we would have had to use modeled Brook Trout and Brown Trout abundances, both of which had substantial prediction error. Second, Zorn et al. (2004) found that incorporating Brook Trout into a Brown Trout model or vice versa explained little additional variability in standing stocks. Third, landscape-scale abundances are largely controlled by abiotic gradients that limit the fitness of populations. Incorporating a competitor with a similar niche would have obscured these important relationships and our ability to learn from them. One implication of not accounting for potential competitors is that trout biomass may be overestimated in areas where the species co-occur. The nonuniform distribution of Brown Trout relative to Brook Trout (i.e., due to stocking) may also contribute to model inaccuracies.

Although there has been much focus on mapping the biophysical supply of ecosystem services (Chan et al. 2006; Gimona and van der Horst 2007; Egoh et al. 2008; Meyer and Grabaum 2008; Kienast et al. 2009) and/or service value (Naidoo and Ricketts 2006; Nelson et al. 2009), relatively few studies in the ecosystem services literature have used robust field data, subjected their models to validation, quantified the uncertainty in their biophysical or ecosystem service estimates, or provided "a sound basis for the conclusions they draw" (Seppelt et al. 2011). Our study did use robust field data with reliable population estimates, thus providing a snapshot of the system over time. We mapped model uncertainty in a spatially explicit way (Figure 6) that can help managers to determine where our model predictions are highly precise and where additional sampling may be needed to strengthen the model results. Maps of uncertainty suggested that our model predictions were most precise for habitats that were most suitable to fisheries. 
This result further reinforces the notion that our moderate to high biomass estimates are reliable, whereas our low estimates should be interpreted conservatively, particularly for the trout species. The internal cross-validation procedure that we used could be improved (1) if independent field data become available or (2) through targeted sampling for the express purpose of model validation (sensu McKenna and Johnson 2011). Notwithstanding future improvements, our models are transparent and, more importantly, do not rely on overly simplified relationships, assumed production functions, or indirect proxies for the service of interest, as is common in the ecosystem services literature (Chan et al. 2006; Naidoo and Ricketts 2006; Troy and Wilson 2006; Egoh et al. 2008).

Our models and maps have numerous potential uses for fisheries managers to examine the productive potential of streams, describe geographic patterns of fisheries, and identify habitats that are candidates for stocking or restoration of locally extirpated stocks (Brewer et al. 2007). Our models also have utility for landscape nutrient management. Excessive anthropogenic nutrients in surface waters are a water quality management priority throughout the world because they are a primary source of impairment to freshwater ecosystems (Plessis and Veelen 1991; USEPA 1996; Smith et al. 1999; Davies and Jackson 2006). In North America, nutrient levels are regulated under the Clean Water Act of 1972 to be protective of designated stream uses such as "fish, shellfish, and wildlife" (USEPA 2000). Nutrient management targets are often set for streams according to the effects they have on aquatic life, and these targets must be quantitatively justified (Dodds and Welch 2000; USEPA 2000). Our results suggest that the biomasses of Brook Trout and Smallmouth Bass in Michigan streams may be maximized at TP concentrations of 13 and $34 \mu \mathrm{g} / \mathrm{L}$, respectively, and that higher concentrations may have detrimental effects on biomass. Our models also suggest that panfish biomass is maximized at about $45 \mu \mathrm{g} / \mathrm{L}$, whereas higher concentrations confer no additional production benefit upon the fishery. These concentrations could potentially serve as benchmarks that provide some level of desired protection to streams in support of fisheries management and management for ecosystem services (Davies and Jackson 2006; Stevenson et al. 2008). Future efforts will be necessary to distinguish among the indirect effects of phosphorus and covarying factors (e.g., fine sediment) as causal mechanisms for the game fish declines associated with higher nutrient concentrations in our study.

Developing a predictive understanding of landscape controls on spatial variability in game fish productivity is a critical research endeavor that can support economic valuation, examination of tradeoffs between ecosystem services, and spatial planning for efficient species conservation and exploitation (Heal et al. 2005). We trained BRT models for defining ecological production functions that predict an output of ecosystem services produced by Michigan rivers. However, societal benefits of fish biomass availability in Michigan rivers can only be determined by considering human demand for the service (Tallis and Polasky 2009). Until our fish standing crop estimates are connected to beneficiaries, we cannot draw detailed conclusions about the benefit or value of this ecosystem service to society. Thus, the essential next step for this research is to quantify angler behaviors relative to fish biomass availability and to assign values to biomass in the rivers where it is produced (see companion paper by Melstrom et al. 2015). With biophysical and economic information in hand, sport fishery managers should be able to utilize new spatial knowledge to improve fisheries management to the benefit of anglers.

\section{ACKNOWLEDGMENTS}

Funding for this research was provided by the U.S. Environmental Protection Agency, Western Ecology Division, to R.J.S. and F.L. We thank Zhen Zhang (Center for Statistical Training and Consulting, Michigan State University), Glenn De'ath, and Jane Elith for assistance in implementing models within R. We also acknowledge Paul Steen for sharing the results of his research, and we are grateful to Troy Zorn, Jeff Schaeffer, Richard Melstrom, Jim McKenna, Chris Holbrook, and an anonymous reviewer for providing valuable input to the manuscript. This article is contribution 1917 of the U.S. Geological Survey Great Lakes Science Center.

\section{REFERENCES}

Argent, D. G., and P. A. Flebbe. 1999. Fine sediment effects on Brook Trout eggs in laboratory streams. Fisheries Research 39:253-262.

Askey, P. J., L. K. Hogberg, J. R. Post, L. J. Jackson, T. Rhodes, and M. S. Thompson. 2007. Spatial patterns in fish biomass and relative trophic level abundance in a wastewater enriched river. Ecology of Freshwater Fish 16:343-353.

Boyd, J., and S. Banzhaf. 2007. What are ecosystem services? The need for standardized environmental accounting units. Ecological Economics 63:616-626.

Brenden, T., and coauthors. 2006. A GIS framework for collecting, managing, and analyzing multiscale landscape variables across large regions for river conservation and management. Pages 49-74 in R. M. Hughes, L. Wang, and P. W. Seelbach, editors. Landscape influences on stream habitats and biological assemblages. American Fisheries Society, Symposium 48, Bethesda, Maryland.

Brewer, S. K. 2013. Channel unit use by Smallmouth Bass: do land-use constraints or quantity of habitat matter? North American Journal of Fisheries Management 33:351-358.

Brewer, S. K., and C. F. Rabeni. 2011. Interactions between natural-occurring landscape conditions and land use influencing the abundance of riverine Smallmouth Bass, Micropterus dolomieu. Canadian Journal of Fisheries and Aquatic Sciences 68:1922-1933.

Brewer, S. K., C. F. Rabeni, S. P. Sowa, and G. Annis. 2007. Natural landscape and stream segment attributes influencing the distribution and relative abundance of riverine Smallmouth Bass in Missouri. North American Journal of Fisheries Management 27:326-341.

Carpenter, S. R., N. F. Caraco, D. L. Correll, R. W. Howarth, A. N. Sharpley, and V. H. Smith. 1998. Nonpoint pollution of surface waters with phosphorus and nitrogen. Ecological Applications 8:559-568.

Chan, K. M. A., M. R. Shaw, D. R. Cameron, E. C. Underwood, and G. C. Daily. 2006. Conservation planning for ecosystem services. PloS (Public Library of Science) Biology [online serial] 4(11):2138-2152. 
Coble, D. W. 1975. Smallmouth Bass. Pages 21-33 in H. Clepper, editor. Black bass biology and management. Sport Fishing Institute, Washington, D.C.

Cooper, G. P., and J. R. Ryckman. 1981. Population estimates by mark-andrecapture. Appendix in J. W. Merna, J. C. Schneider, G. R. Alexander, W. D. Alward, and R. L. Eshenroder, editors. Manual of fisheries survey methods. Michigan Department of Natural Resources, Fisheries Management Report 9, Ann Arbor.

Creque, S. M., E. S. Rutherford, and T. G. Zorn. 2005. Use of GIS-derived landscape-scale habitat features to explain spatial patterns of fish density in Michigan rivers. North American Journal of Fisheries Management 25:1411-1425.

Curry, R. A., and W. S. MacNeill. 2004. Population-level responses to sediment during early life in Brook Trout. Journal of the North American Benthological Society 23:140-150.

Davies, S. P., and S. K. Jackson. 2006. The biological condition gradient: a descriptive model for interpreting change in aquatic ecosystems. Ecological Applications 16:1251-1266.

de Groot, R. S., R. Alkemade, L. Braat, L. Hein, and L. Willemen. 2010. Challenges in integrating the concept of ecosystem services and values in landscape planning, management and decision making. Ecological Complexity 7:260-272.

deBruyn, A. M. H., D. J. Marcogliese, and J. B. Rasmussen. 2003. The role of sewage in a large river food web. Canadian Journal of Fisheries and Aquatic Sciences 60:1332-1344.

Diana, J. S. 2004. Biology and ecology of fishes, 2nd edition. Cooper Publishing Group, Traverse City, Michigan.

Dodds, W. K., and B. J. F. Biggs. 2002. Water velocity attenuation by stream periphyton and macrophytes in relatino to growth form and architecture. Journal of the North American Benthological Society 21:2-15.

Dodds, W. K., and E. B. Welch. 2000. Establishing nutrient criteria in streams. Journal of the North American Benthological Society 19:186-196.

Egoh, B., B. Reyers, M. Rouget, D. M. Richardson, D. C. Le Maitre, and A. S. van Jaarsveld. 2008. Mapping ecosystem services for planning and management. Agriculture Ecosystems and Environment 127:135-140.

Elith, J., J. R. Leathwick, and T. Hastie. 2008. A working guide to boosted regression trees. Journal of Animal Ecology 77:802-813.

Fausch, K. D., C. L. Hawkes, and M. G. Parsons. 1988. Models that predict standing crop of stream fish from habitat variables: 1950-85. U.S. Forest Service General Technical Report PNW-GTR-213.

Fausch, K. D., and R. J. White. 1981. Competition between Brook Trout (Salvelinus fontinalis) and Brown Trout (Salmo trutta) for positions in a Michigan stream. Canadian Journal of Fisheries and Aquatic Sciences 38:12201227.

Friedman, J. H. 2001. Greedy function approximation: a gradient boosting machine. Annals of Statistics 29:1189-1232.

Friedman, J. H., and J. J. Meulman. 2003. Multiple additive regression trees with application in epidemiology. Statistics in Medicine 22:1365-1381.

Frissell, C. A., W. J. Liss, C. E. Warren, and M. D. Hurley. 1986. A hierarchical framework for stream habitat classification: viewing streams in a watershed context. Environmental Management 10:199-214.

Gido, K. B., J. A. Falke, R. M. Oakes, and K. J. Hase. 2006. Fish-habitat relations across spatial scales in prairie streams. Pages 265-285 in R. M. Hughes, L. Wang, and P. W. Seelbach, editors. Landscape influences on stream habitats and biological assemblages. American Fisheries Society, Symposium 48, Bethesda, Maryland.

Gimona, A., and D. van der Horst. 2007. Mapping hotspots of multiple landscape functions: a case study on farmland afforestation in Scotland. Landscape Ecology 22:1255-1264.

GLSC (Great Lakes Science Center). 2006. The Great Lakes aquatic GAP project. U.S. Geological Survey, Ann Arbor, Michigan.

Hart, D. D., and C. T. Robinson. 1990. Resource limitation in a stream community: phosphorus enrichment effects on periphyton and grazers. Ecology 71:1494-1502.
Heal, G. M., E. B. Barbier, K. J. Boyle, A. P. Covich, S. P. Gloss, C. H. Hershner, J. P. Hoehn, C. P. Pringle, S. Polasky, and K. Segerson. 2005. Valuing ecosystem services: toward better environmental decision-making. National Academies Press, Washington, D.C.

Hokanson, K. E. F. 1977. Temperature requirements of some percids and adaptations to seasonal temperature cycle. Journal of the Fisheries Research Board of Canada 34:1524-1550.

Horrall, R. M. 1981. Behavioral stock-isolating mechanisms in Great Lakes fishes with special reference to homing and site imprinting. Canadian Journal of Fisheries and Aquatic Sciences 38:1481-1496.

Hoyer, M. V., and D. E. Canfield Jr. 1991. A phosphorus-fish standing crop relationship for streams? Lake and Reservoir Management 7:25-32.

Johnson, B. L., D. L. Smith, and F. R. Carline. 1988. Habitat preferences, survival, growth, foods, and harvests of Walleye and Walleye $\times$ Sauger hybrids. North American Journal of Fisheries Management 8:292-304.

Johnston, N. T., C. J. Perrin, P. A. Slaney, and B. R. Ward. 1990. Increased juvenile salmonid growth by whole-river fertilization. Canadian Journal of Fisheries and Aquatic Sciences 47:862-872.

Jones, D. R., J. W. Kiceniuk, and O. S. Bamford. 1974. Evaluation of swimming performance of several fish species from Mackenzie River. Journal of the Fisheries Research Board of Canada 31:1641-1647.

Kienast, F., J. Bolliger, M. Potschin, R. S. de Groot, P. H. Verburg, I. Heller, D. Wascher, and R. Haines-Young. 2009. Assessing landscape functions with broad-scale environmental data: insights gained from a prototype development for Europe. Environmental Management 44:1099-1120.

Kleiman, R. 1995. Modeling water quality in Michigan rivers from landscape variables. Master's thesis. University of Michigan, Ann Arbor.

Kotchen, M., M. Moore, F. Lupi, and E. Rutherford. 2006. Environmental constraints on hydropower: an ex-post benefit-cost analysis of dam relicensing in Michigan. Land Economics 82:384-403.

Lambert, D. 1992. Zero-inflated poisson regression, with an application to defects in manufacturing. Technometrics 34:1-14.

Lyons, J., L. Wang, and T. D. Simonson. 1996. Development and validation of an index of biotic integrity for coldwater streams in Wisconsin. North American Journal of Fisheries Management 16:241-256.

McKenna, J. E. Jr., and J. H. Johnson. 2011. Landscape models of Brook Trout abundance and distribution in lotic habitat with field validation. North American Journal of Fisheries Management 31:742-756.

McKenna, J. E. Jr., R. P. McDonald, C. Castiglione, S. S. Morrison, K. P. Kowalski, and D. R. Passino-Reader. 2006. A broadscale fish-habitat model development process: Genesee basin, New York. Pages 533-554 in R. M. Hughes, L. Wang, and P. W. Seelbach, editors. Landscape influences on stream habitats and biological assemblages. American Fisheries Society, Symposium 48, Bethesda, Maryland.

McKenna, J. E. Jr., M. T. Slattery, and K. M. Clifford. 2013. Broad-scale patterns of Brook Trout responses to introduced Brown Trout in New York. North American Journal of Fisheries Management 33:1221-1235.

McRae, B. J., and J. S. Diana. 2005. Factors influencing density of age-0 Brown Trout and Brook Trout in the Au Sable River, Michigan. Transactions of the American Fisheries Society 134:132-140.

MDNR (Michigan Department of Natural Resources). 2010. Michigan trout lakes and streams 2008. MDNR, Institute for Fisheries Research, Ann Arbor.

Melstrom, R. T., and F. Lupi. 2013. Valuing recreational fishing in the Great Lakes. North American Journal of Fisheries Management 33:1184-1193.

Melstrom, R. T., F. Lupi, P. C. Esselman, and R. J. Stevenson. 2015. Valuing recreational fishing quality at rivers and streams. Water Resources Research 51:140-150.

Merron, G. S. 1982. Growth rate of Brown Trout (Salmo trutta) in areas of the Au Sable River, Michigan, before and after domestic sewage diversion. Michigan Department of Natural Resources, Fisheries Research Report 1900, Ann Arbor.

Meyer, B. C., and R. Grabaum. 2008. MULBO: model framework for multicriteria landscape assessment and optimisation, a support system for spatial land use decisions. Landscape Research 33:155-179. 
Millennium Ecosystem Assessment. 2005. Ecosystems and human well-being: synthesis. Island Press, Washington, D.C.

Miltner, R. J., and E. T. Rankin. 1998. Primary nutrients and the biotic integrity of rivers and streams. Freshwater Biology 40:145-158.

Naidoo, R., and T. H. Ricketts. 2006. Mapping the economic costs and benefits of conservation. PloS (Public Library of Science) Biology [online serial] 4 (11):2153-2164.

Nelson, E., G. Mendoza, J. Regetz, S. Polasky, H. Tallis, D. R. Cameron, K. M. A. Chan, G. C. Daily, J. Goldstein, P. M. Kareiva, E. Lonsdorf, R. Naidoo, T. H. Ricketts, and M. R. Shaw. 2009. Modeling multiple ecosystem services, biodiversity conservation, commodity production, and tradeoffs at landscape scales. Frontiers in Ecology and the Environment 7:4-11.

Olcott, P. G. 1992. Groundwater atlas of the United States: Iowa, Michigan, Minnesota, Wisconsin. U.S. Geological Survey, Reston, Virginia.

Page, L. M., and B. M. Burr. 1991. A field guide to freshwater fishes: North America north of Mexico. Houghton Mifflin, New York.

Peterson, B. J., L Deegan, J. Helfrich, J. E. Hobbie, M. Hullar, B. Moller, T. E. Ford, A. Hershey, A. Hiltner, G. Kipphut, M. A. Lock, D. M. Fiebig, V. McKinley, M. C. Miller, J. R. Vestal, R. Ventullo, and G. Volk. 1993. Biological responses of a tundra river to fertilization. Ecology 74:653-672.

Peterson, J. T., and T. J. Kwak. 1999. Modeling the effects of land use and climate change on riverine Smallmouth Bass. Ecological Applications 9:1391-1404

Plessis, H., and M. Veelen. 1991. Water quality: salinization and eutrophication time series trends in South Africa. South African Journal of Science 87:11-16.

Poff, N. L. 1997. Landscape filters and species traits: towards mechanistic understanding and prediction in stream ecology. Journal of the North American Benthological Society 16:391-409.

Pritt, J. J., M. R. DuFour, C. M. Mayer, P. M. Kocovsky, J. T. Tyson, E. J. Weimer, C. S. Vandergoot. 2013. Including independent estimates and uncertainty to quantify total abundance of fish migrating in a large river system: Walleye (Sander vitreus) in the Maumee River, Ohio. Canadian Journal of Fisheries and Aquatic Sciences 70:803-814.

R Development Core Team. 2013. R: a language and environment for statistical computing. R Foundation for Statistical Computing, Vienna.

Rahel, F. J., and W. A. Hubert. 1991. Fish assemblages and habitat gradients in a RockyMountain-Great Plains stream: biotic zonation and additive patterns of community change. Transactions of the American Fisheries Society 120:319-332.

Randall, R. G., J. R. M. Kelso, and C. K. Minns. 1995. Fish production in fresh waters: are rivers more productive than lakes? Canadian Journal of Fisheries and Aquatic Sciences 52:631-643.

Seelbach, P. W., and M. J. Wiley. 1997. Overview of the Michigan rivers inventory (MRI) project. Michigan Department of Natural Resources, Fisheries Technical Report 97-3, Ann Arbor.

Seppelt, R., C. F. Dormann, F. V. Eppink, S. Lautenbach, and S. Schmidt. 2011. A quantitative review of ecosystem service studies: approaches, shortcomings and the road ahead. Journal of Applied Ecology 48:630-636.

Slaney, P. A., B. R. Ward, and J. C. Wightman. 2003. Experimental nutrient addition to the Keogh River and application to the Salmon River in coastal British Columbia. Pages 111-126 in J. G. Stockner, editor. Nutrients in salmonid ecosystems: sustaining production and biodiversity. American Fisheries Society, Symposium 34, Bethesda, Maryland.

Slavik, K., B. J. Peterson, L. A. Deegan, W. B. Bowden, A. E. Hershey, and J. E. Hobbie. 2004. Long-term responses of the Kuparuk River ecosystem to phosphorus fertilization. Ecology 85:939-954.

Smith, R. A., R. B. Alexander, and G. E. Schwarz. 2003. Natural background concentrations of nutrients in streams and rivers of the conterminous United States. Environmental Science and Technology 37:3039-3047.

Smith, V. H., G. D. Tilman, and J. C. Nekola. 1999. Eutrophication: impacts of excess nutrient inputs on freshwater, marine, and terrestrial ecosystems. Environmental Pollution 100:179-196.
Snieszko, S. F. 1974. Effects of environmental stress on outbreaks of infectious diseases of fishes. Journal of Fish Biology 6:197-208.

Southwick Associates. 2007. Sportfishing in America: an economic engine and conservation powerhouse. American Sportfishing Association, Alexandria, Virginia.

Sowa, S. P., and C. F. Rabeni. 1995. Regional evaluation of the relation of habitat to distribution and abundance of Smallmouth Bass in Missouri streams. Transactions of the American Fisheries Society 124:240-251.

Stanfield, L. W., S. F. Gibson, and J. A. Borwick. 2006. Using a landscape approach to identify the distribution and density patterns of salmonids in Lake Ontario tributaries. Pages 601-621 in R. M. Hughes, L. Wang, and P. W. Seelbach, editors. Landscape influences on stream habitats and biological assemblages. American Fisheries Society, Symposium 48, Bethesda, Maryland.

Steen, P. J., T. G. Zorn, P. W. Seelbach, and J. S. Schaeffer. 2008. Classification tree models for predicting distributions of Michigan stream fish from landscape variables. Transactions of the American Fisheries Society 137:976-996.

Stevenson, R. J., B. H. Hill, A. T. Herlihy, L. L. Yuan, and S. B. Norton. 2008. Algae-P relationships, thresholds, and frequency distributions guide nutrient criterion development. Journal of the North American Benthological Society 27:783-799.

Stoneman, C. L., and M. L. Jones. 2000. The influence of habitat features on the biomass and distribution of three species of southern Ontario stream salmonines. Transactions of the American Fisheries Society 129:639-657.

Stranko, S. A., R. H. Hilderbrand, R. P. Morgan II, M. W. Staley, A. J. Becker, A. Roseberry-Lincoln, E. S. Perry, and P. T. Jacobson. 2008. Brook Trout declines with land cover and temperature changes in Maryland. North American Journal of Fisheries Management 28:1223-1232.

Stuber, R. J., G. Gebhart, and O. E. Maughan. 1982a. Habitat suitability index models: Bluegill. U.S. Fish and Wildlife Service FWS/OBS-82/10.8.

Stuber, R. J., G. Gebhart, and O. E. Maughan. 1982b. Habitat suitability index models: Largemouth Bass. U.S. Fish and Wildlife Service FWS/OBS-82/ 10.16.

Tallis, H., and S. Polasky. 2009. Mapping and valuing ecosystem services as an approach for conservation and natural resource management. Annals of the New York Academy of Sciences 1162:265-283.

Theil, H. 1961. Economic forecasts and policy. North-Holland, Amsterdam.

Troy, A., and M. A. Wilson. 2006. Mapping ecosystem services: practical challenges and opportunities in linking GIS and value transfer. Ecological Economics 60:435-449.

USEPA (U.S. Environmental Protection Agency). 1996. National nutrient assessment workshop proceedings. USEPA, Office of Water, Washington, D.C.

USEPA (U.S. Environmental Protection Agency). 2000. Nutrient criteria technical guidance manual: rivers and streams. USEPA, Office of Water, Washington, D.C.

USEPA (U.S. Environmental Protection Agency) and USGS (U.S. Geological Survey). 2005. National Hydrography Dataset Plus (NHDPlus) version 1.0. USEPA, Washington, D.C. Available: http://www.horizon-systems.com/ nhdplus/. (February 2015).

Vannote, R. L., G. W. Minshall, K. W. Cummins, J. R. Sedell, and C. E. Cushing. 1980. River continuum concept. Canadian Journal of Fisheries and Aquatic Sciences 37:130-137.

Waite, I. R., and K. D. Carpenter. 2000. Associations among fish assemblage structure and environmental variables in Willamette basin streams, Oregon. Transactions of the American Fisheries Society 129:754-770.

Wehrly, K. E., M. J. Wiley, and P. W. Seelbach. 2003. Classifying regional variation in thermal regime based on stream fish community patterns. Transactions of the American Fisheries Society 132:18-38.

Welch, E. B., J. M. Quinn, and C. W. Hickey. 1992. Periphyton biomass related to point-source nutrient enrichment in seven New Zealand streams. Water Resources 26:669-675. 
Wenger, S. J., and M. C. Freeman. 2008. Estimating species occurrence, abundance, and detection probability using zero-inflated distributions. Ecology 89:2953-2959.

Wiley, M. J., S. L. Kohler, and P. W. Seelbach. 1997. Reconciling landscape and local views of aquatic communities: lessons from Michigan trout streams. Freshwater Biology 37:133-148.

Wiley, M. J., L. L. Osborne, and R. W. Larimore. 1990. Longitudinal structure of an agricultural prairie river system and its relationship to current stream ecosystem theory. Canadian Journal of Fisheries and Aquatic Sciences 47:373-384.

Zippin, C. 1958. The removal method of population estimation. Journal of Wildlife Management 22:82-90.

Zorn, T., P. W. Seelbach, and M. J. Wiley. 1998. Patterns in the distributions of stream fishes in Michigan's Lower Peninsula. Michigan Department of Natural Resources, Fisheries Research Report 2035, Ann Arbor.

Zorn, T., and M. J. Wiley. 2004. Untangling relationships between river habitat and fishes in Michigan's Lower Peninsula with covariance structure analysis. Michigan Department of Natural Resources, Fisheries Research Report 2073, Ann Arbor.

Zorn, T. G., P. W. Seelbach, and M. J. Wiley. 2002. Distributions of stream fishes and their relationship to stream size and hydrology in Michigan's Lower Peninsula. Transactions of the American Fisheries Society 131: 70-85.

Zorn, T. G., P. W. Seelbach, and M. J. Wiley. 2004. Utility of species-specific, multiple linear regression models for prediction of fish assemblages in rivers of Michigan's Lower Peninsula. Michigan Department of Natural Resources, Fisheries Division, Research Report 2072, Lansing.

Zorn, T. G., P. W. Seelbach, and M. J. Wiley. 2009. Relationships between habitat and fish density in Michigan streams. Michigan Department of Natural Resources, Fisheries Research Report 2091, Ann Arbor.

Zorn, T. G., and M. J. Wiley. 2006. Influence of landscape characteristics on local habitat and fish biomass in streams of Michigan's Lower Peninsula. Pages 375-393 in R. M. Hughes, L. Wang, and P. W. Seelbach, editors. Landscap influences on stream habitats and biological assemblages. American Fisheries Society, Symposium 48, Bethesda, Maryland. 